\title{
Effects of shrimp density on transmission of penaeid acute viremia in Penaeus japonicus by cannibalism and the waterborne route
}

\author{
J. L. Wu ${ }^{1}$, A. Namikoshi ${ }^{1}$, T. Nishizawa ${ }^{1}$, K. Mushiake ${ }^{2, *}$, K. Teruya ${ }^{2}$, K. Muroga ${ }^{1, * *}$ \\ ${ }^{1}$ Laboratory of Fish Pathology, Faculty of Applied Biological Science, Hiroshima University, Higashihiroshima 739-8528, Japan \\ ${ }^{2}$ Kamiura Station of Japan Sea-Farming Association, Kamiura, Oita 879-2602, Japan
}

\begin{abstract}
To investigate the effects of shrimp density on mortalities of Penaeus japonicus in experimental penaeid acute viremia (= white spot syndrome), shrimp injected intramuscularly with penaeid rod-shaped DNA virus (PRDV) were reared at different densities. In Expt 1, challenged $\left(10^{-6}\right.$ dilution of a PRDV preparation) shrimp were reared collectively in a tank or individually in separate chamber units. A significant difference in cumulative mortalities was found between collectively $(75.6 \%)$ and individually $(1.2 \%)$ reared groups after $30 \mathrm{~d}$. In Expt 2, effects of density on mortality were clearly shown when challenged $\left(10^{-5}\right.$ dilution) shrimp were reared collectively in tanks at high (260 shrimp $\left.\mathrm{m}^{-2}\right)$, middle (135 shrimp $\left.\mathrm{m}^{-2}\right)$ and low densities $\left(73\right.$ shrimp $\left.\mathrm{m}^{-2}\right)$. The cumulative mortalities for $14 \mathrm{~d}$ in the high, middle and low density groups were 72,46 and $18 \%$, respectively. In Expt 3, challenged $\left(10^{-5}\right.$ dilution) shrimp were reared collectively in 3 tanks (Groups A, B and C) at the same high density $\left(260\right.$ shrimp $\left.\mathrm{m}^{-2}\right)$ : Group A, dead shrimp were immediately removed to avoid transmission of the pathogen through cannibalism and the waterborne route; Group B, dead shrimp were removed at scheduled times but were separated from living shrimp by a net partition to avoid cannibalism; and Group C, dead shrimp were removed twice a day at scheduled times. Resulting cumulative mortalities for $20 \mathrm{~d}$ in Groups A, B and C were 4, 24 and $64 \%$, respectively. These results show that the higher mortalities occur in $P$. japonicus reared at the higher densities in experimental PRDV infection, and this phenomenon is caused mainly by a higher opportunity of horizontal transmission of the virus through cannibalism and the waterborne route.
\end{abstract}

KEY WORDS: Penaeus japonicus · Penaeid acute viremia $\cdot$ Density $\cdot$ Cannibalism $\cdot$ Waterborne transmission $\cdot$ White spot syndrome

Resale or republication not permitted without written consent of the publisher

\section{INTRODUCTION}

Outbreaks of a new viral disease in cultured penaeid shrimp, now generally called white spot syndrome (WSS) or white spot disease, have been reported since around 1994 from various countries in Asia such as China (Chou et al. 1995, Huang et al. 1995), Thailand (Wongteerasupaya et al. 1995), Malaysia (Wang et al. 1999), India (Mohan et al. 1998), Korea (Park et al.

\footnotetext{
*Present address: Goto Station of Japan Sea-Farming Association, Minami-Matsura-gun, Tamanoura-cho, Nagasaki 853-0501, Japan

**Corresponding author. E-mail: fpath@hiroshima-u.ac.jp
}

1998) and the Philippines (Magbanua et al. 2000), and the disease has already spread to the Americas (Nunan et al. 1998). The exact taxonomic position of the causative virus has not been settled (van Hulten et al. 2000).

The presence of white spots in the exoskeleton is said to be a principal clinical sign of WSS (Lightner 1996), but similar white spots could be observed in healthy Penaeus japonicus (Momoyama et al. 1994) and in P. monodon infected with bacteria (Wang et al. 2000). Thus, we still use the name 'penaeid acute viremia' (PAV), although the causative virus of PAV (penaeid rod-shaped DNA virus [PRDV]) is known to be the same as WSS virus (WSSV). Methods for diagnosis of PAV or WSS (Inouye et al. 1994, Momoyama 
et al. 1995, Wang et al. 1999) and detection of the causative virus by PCR (Kimura et al. 1996, Lo et al. 1996), in situ hybridization (Durand et al. 1996, Wongteerasupaya et al. 1996), dot blot hybridization (Chang et al. 1998) and monoclonal antibodies (Zhan et al. 1999) have been described. In Japan, PAV has also been occurring since 1993 (Nakano et al. 1994); however, owing to effective segregation of infected spawners by PCR-based detection of PRDV, a method for controlling this disease in hatcheries has been established (Mushiake et al. 1999).

Recently, a quasi-immune response of kuruma prawns Penaeus japonicus against PRDV was shown in natural and experimental survivors of PAV infection by experimental PRDV challenge (Venegas et al. 2000). During preparation of experimental PAV survivors, a significant difference in cumulative mortalities was observed between the shrimp group kept collectively in a tank and the group kept individually in separate chambers. This phenomenon was thought to be associated with stress, which might reduce the resistance of the shrimp collectively reared at a high shrimp density (Venegas et al. 2000).

In the present study, we have confirmed that higher mortalities were produced in shrimp reared at higher densities in experimental PAV in Penaeus japonicus, and we have found that this phenomenon is associated with enhanced opportunity of horizontal transmission of the pathogen through cannibalism and the waterborne route.

\section{MATERIALS AND METHODS}

Shrimp. PRDV-free kuruma prawns, produced in the Kamiura Station of the Japan Sea-Farming Association (JASFA) were used for this study. They were reared in an indoor $50 \mathrm{~m}^{3}$ tank supplied with ozonated seawater and received commercial pelleted diet before and during the experiments.

Virus. Adult prawns (mean body weight [MBW] $100 \mathrm{~g}$ ) were inoculated intramuscularly (IM) with $200 \mu \mathrm{l}$ of $10^{-3}$ dilution of a virus source $\left(\mathrm{LD}_{50}: 10^{-9.1} \mathrm{ml}\right.$ $\mathrm{g}^{-1}$, prepared from naturally PRDV-infected juveniles of Penaeus japonicus). The hemolymph was withdrawn with 4 -fold sterile PBS from moribund prawns after $3 \mathrm{~d}$, divided into $0.3 \mathrm{ml}$ aliquots, and stored at $-80^{\circ} \mathrm{C}$. Before each experiment, an aliquot was thawed and centrifuged at $1500 \times \mathrm{g}$ at $4^{\circ} \mathrm{C}$ for $10 \mathrm{~min}$. The supernatant was diluted to required concentrations and inoculated into shrimp by IM injection.

PCR detection for PRDV. DNA was extracted from the body muscle of dead shrimp following a protocol designed in our laboratory (Nonaka et al. 1998) and submitted to a PCR test using the primer set (Primer 1:
5'-ATC ATG GCT GCT TCA CAG AC-3', and Primer 2: 5'-GGC TGG AGA GGA CAA GAC AT-3') designed by Kimura et al. (1996). Briefly, a muscle sample (0.2 g) was homogenized in $300 \mu \mathrm{l}$ TE buffer $(10 \mathrm{mM}$ Tris-HCl, $1 \mathrm{mM}$ EDTA, pH 8.0) and digested with Proteinase K $\left(1 \mathrm{mg} \mathrm{ml}^{-1}\right)$ and SDS $(1 \% \mathrm{v} / \mathrm{v})$ at $37^{\circ} \mathrm{C}$ for $15 \mathrm{~min}$. The solution was extracted twice with TE-saturated phenol and once with chloroform/isoamylalcohol (24:1). Nucleic acids were precipitated by absolute ethanol with a final concentration of $0.5 \mathrm{M}$ ammonium acetate. After centrifugation at $12000 \times g$ for $15 \mathrm{~min}$, the pellet was dissolved in TE buffer and treated with RNase $(20 \mu \mathrm{g}$ $\mathrm{ml}^{-1}$ ). Then the DNA was recovered by $20 \%$ polyethylene glycol 6000 solution, washed with $70 \%$ (v/v) ethanol and dried. Thereafter, the DNA was redissolved in TE buffer and submitted to PCR amplification (30 cycles) for a $982 \mathrm{bp}$ amplicon in a temperature control system (PC-800, Astec Ltd, Shimencho, Kasuyagun, Fukuoka Pref., Japan). PCR products were examined by electrophoresis using $1.5 \%$ agarose gels.

Expt 1. Effects of rearing conditions on mortality in experimental PAV. Each shrimp (MBW $1.1 \mathrm{~g}$ ) was inoculated with $20 \mu \mathrm{l}$ of $10^{-6}$ dilution of the virus preparation, then reared individually (Ind group) in separate chamber units ('shrimp apartment'; Fig. 1) $\left(130 \mathrm{~cm}^{2}\right.$

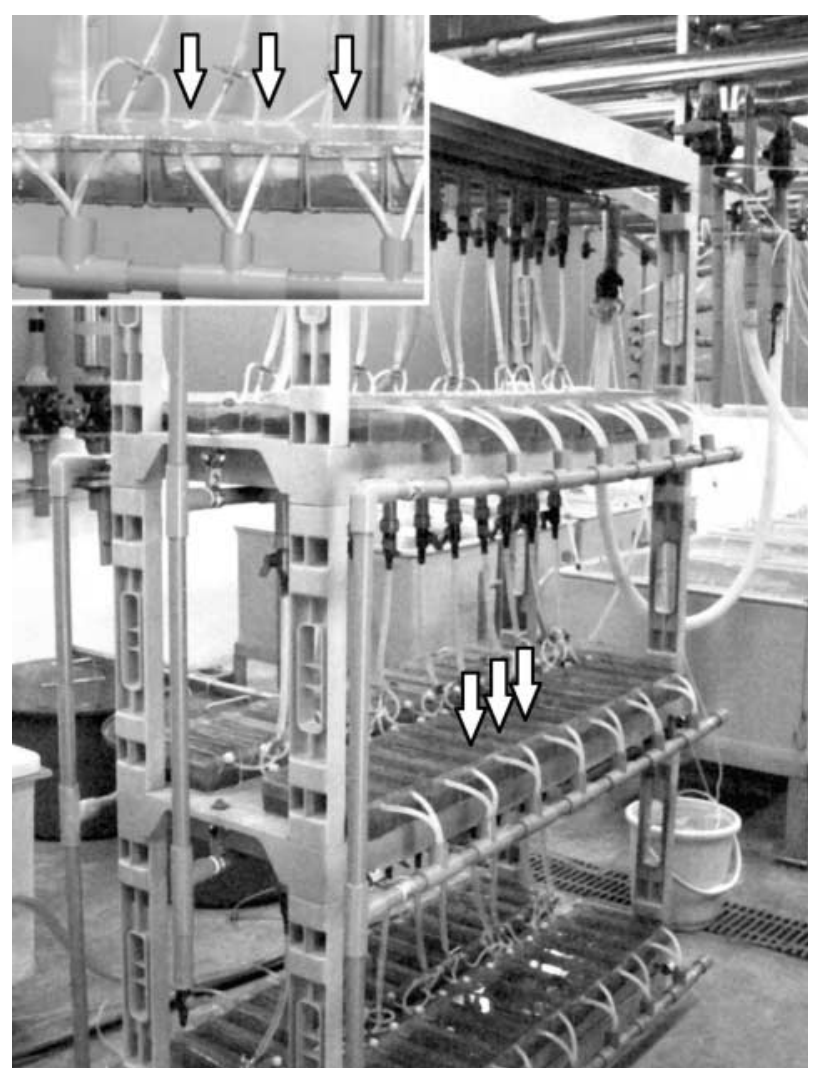

Fig. 1. A hand-made separate chamber unit consisting of 84 chambers (arrows) for individual rearing 
shrimp $^{-1}$ chamber $^{-1}=77$ shrimp $\mathrm{m}^{-2}$, each chamber containing $600 \mathrm{ml}$ seawater, $\mathrm{n}=171$ ) or collectively (Coll group) in a $500 \mathrm{l}$ plastic tank (222 shrimp $\mathrm{m}^{-2}$, $\mathrm{n}=176$ ) and fed commercial diet at a quantity of $5 \%$ MBW. Both types of containers were provided with sand beds and supplied with temperature-controlled $\left(24 \pm 0.5^{\circ} \mathrm{C}\right)$ and ozonated seawater. For the Ind group, the water exchange rate was $100 \%$ every 6 to $8 \mathrm{~min}$ but with no aeration. For the Coll group, the water exchange rate was $100 \%$ every $6 \mathrm{~h}$ with gentle aeration. Dead shrimp were sampled for PRDV detection by PCR.

Expt 2. Effects of shrimp density on mortality in experimental PAV. Individual shrimp (MBW $1.1 \mathrm{~g}$ ) were IM injected with $20 \mu \mathrm{l}$ of a $10^{-4}$ dilution of the virus preparation and divided into 4 groups (Expt 2a). Three groups were reared collectively at different densities in 301 (bottom surface $960 \mathrm{~cm}^{2}$ ) tanks, designated high (25 shrimp tank ${ }^{-1}=260$ shrimp $\mathrm{m}^{-2}, 1$ tank), middle (13 shrimp tank $\mathrm{k}^{-1}=135$ shrimp $\mathrm{m}^{-2}, 2$ tanks) and low ( 7 shrimp tank $\mathrm{k}^{-1}=73$ shrimp $\mathrm{m}^{-2}, 4$ tanks) densities. Shrimp in the remaining group were maintained individually in separate chambers $\left(130 \mathrm{~cm}^{2}\right.$ shrimp $^{-1}$, $\mathrm{n}=25$ ). A control group injected with PBS was reared collectively in a 301 tank at the high density (260 shrimp $\mathrm{m}^{-2}, \mathrm{n}=25$ ). A similar experiment (Expt $2 \mathrm{~b}$ ) consisting of 4 groups of shrimp IM injected with a lower dose $\left(10^{-5}\right.$ dilution) of the virus or PBS was conducted. Rearing conditions, including sand beds, water temperature, water exchange rates and feeding rates, were the same as in Expt 1. During the experimental period of $10 \mathrm{~d}$ for Expt 2a or $14 \mathrm{~d}$ for Expt 2b, all dead shrimp were collected twice a day at 08:00 and 20:00 h, and subjected to PCR tests.

Expt 3. Effects of cannibalism and waterborne transmission on mortality in experimental PAV. Shrimp (MBW $1.9 \mathrm{~g}$ ) were IM challenged with $50 \mu \mathrm{l} \mathrm{shrimp}{ }^{-1}$ of a $10^{-5}$ dilution of the virus and kept collectively in 3 tanks (Groups A, B and C) at the same high density (260 shrimp $\left.\mathrm{m}^{-2}, \mathrm{n}=25\right)$. A control group $(\mathrm{n}=25)$ injected with $50 \mu \mathrm{l}$ PBS was reared under the same conditions as the experimental groups. All shrimp were reared using the same methods as in Expt 1 except that dead shrimp were removed differently for each group over $20 \mathrm{~d}$ of the experiment: Group A, dead shrimp were immediately removed from the tank by continuous observation over $10 \mathrm{~d}$ in 3 shifts of $8 \mathrm{~h}$; Group B, dead shrimp were immediately transferred into a small net placed in the same tank to avoid cannibalism and then removed at 08:00 or 20:00 h; Group $\mathrm{C}$, dead shrimp were removed twice a day at 08:00 and 20:00 h. Dead shrimp with appendages, tails or compound eyes missing were counted as cannibalized in determining the cannibalism rate. All dead shrimp were subjected to PCR checks for PRDV.
Statistical analyses. Differences in cumulative mortalities between groups were analyzed by $\chi^{2}$ tests at the $5 \%$ level of significance.

\section{RESULTS}

\section{Expt 1. Effects of rearing conditions}

The cumulative mortality of shrimp reared individually for $30 \mathrm{~d}$ in the separate chambers was $1.2 \%$ (2 of 171), while that of shrimp reared collectively in the 5001 tank was $75.6 \%$ (133 of 176) (Fig. 2). Statistical analysis revealed a significant difference between the Ind and Coll groups ( $\mathrm{p}<0.05)$. Results of PCR detection for PRDV were 0 of 2 (number of positive shrimp out of number of shrimp tested) in the Ind group and 20 of 23 in the Coll group.

\section{Expt 2. Effects of shrimp density}

In Expt 2a, where shrimp were challenged with a high dose $\left(10^{-4}\right.$ dilution) of PRDV, cumulative mortalities reached 80, 65, 57 and $68 \%$ in the Coll groups at high, middle and low densities, and in the Ind group, respectively, on Day 10 postinoculation (Fig. 3). Results of PCR checks for PRDV in dead shrimp in the 4 groups were 9 of 10, 10 of 10, 9 of 10 and 17 of 17 , respectively. A positive correlation between density and mortality was observed, but no significant differences in mortalities were found among these groups.

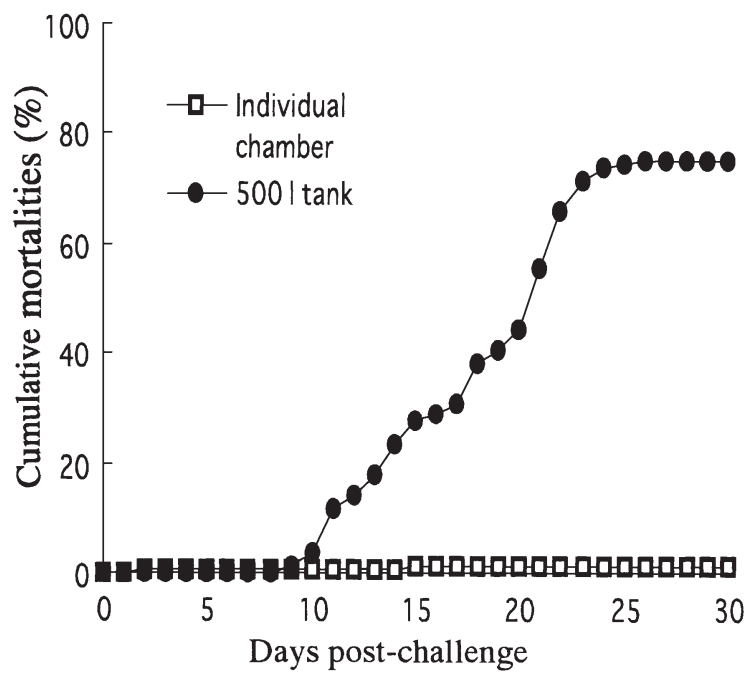

Fig. 2. Cumulative mortalities of Penaeus japonicus challenged by intramuscular injection with penaeid rod-shaped DNA virus (PRDV) $\left(10^{-6}\right.$ dilution) and reared individually ( $\mathrm{n}=$ $171)$ in separate chambers or collectively $(n=176)$ in a 5001 tank (Expt 1) 


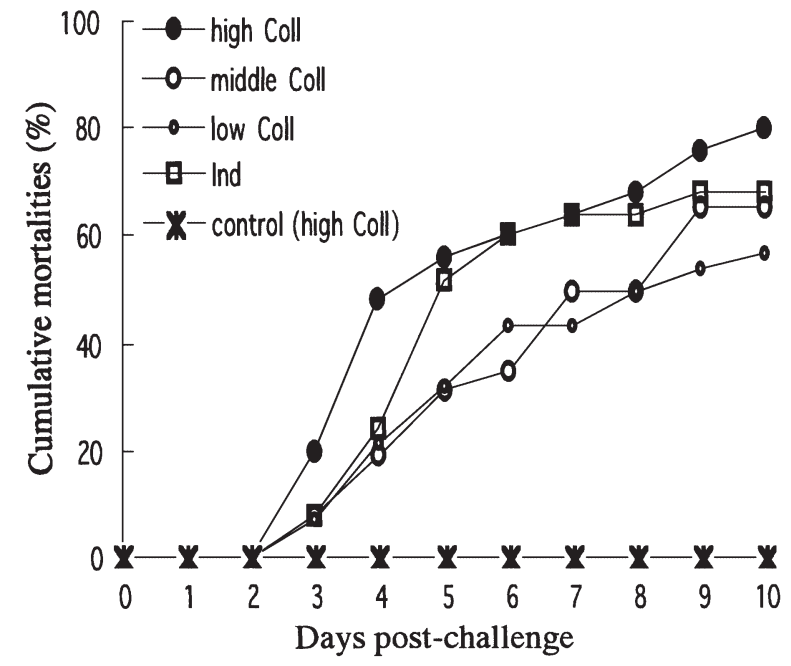

Fig. 3. Cumulative mortalities of Penaeus japonicus challenged by IM injection with PRDV $\left(10^{-4}\right.$ dilution) and reared collectively (Coll) in tanks at 3 different densities or individually (Ind) in separate chambers (Expt 2a). Control shrimp were injected with PBS

In Expt $2 \mathrm{~b}$, where shrimp were challenged with a low dose $\left(10^{-5}\right.$ dilution) of PRDV, cumulative mortalities reached $72,46,18$ and $32 \%$ on Day 14 in the 4 groups, respectively (Fig. 4). Results of PCR checks for PRDV in dead shrimp in the 4 groups were 15 of 16,12 of 12,4 of 4 and 5 of 8 , respectively. A significant difference in cumulative mortalities was observed $(p<$ 0.05 ) between the high and low density groups, but not between the low density Coll group and Ind group, or

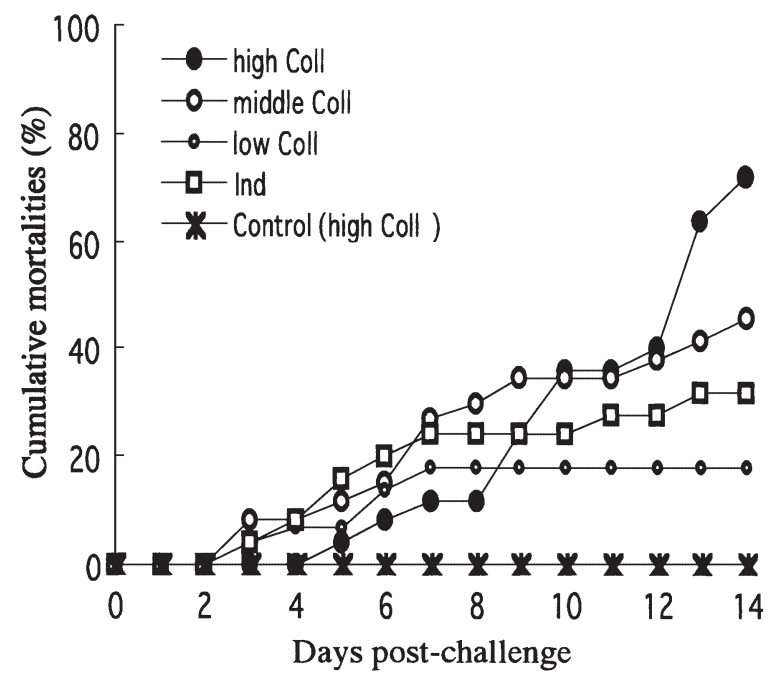

Fig. 4. Cumulative mortalities of Penaeus japonicus challenged by IM injection with PRDV $\left(10^{-5}\right.$ dilution) and reared collectively (Coll) in tanks at 3 different densities or individually (Ind) in separate chambers (Expt 2b). Control shrimp were injected with PBS the middle density Coll group and Ind group. No mortalities were observed in the control groups in Expt 2a or $2 \mathrm{~b}$. Cannibalism was frequently observed in the high and middle density groups but not in the low density group.

\section{Expt 3. Effects of cannibalism and waterborne transmission}

The results presented in Fig. 5 indicate that cannibalism exerted a significant influence on the cumulative mortalities when PRDV-challenged shrimp were collectively reared at a high density. The cumulative mortalities on Day 20 in Groups A, B, C and control were $4,24,64$ and $0 \%$, respectively. Statistical tests showed a significant difference between Groups B and $\mathrm{C}$ as well as Groups $\mathrm{A}$ and $\mathrm{C}$, but not between Groups A and B. Results of PCR detection for PRDV in dead shrimp in Groups A, B and C were 1 of 1, 6 of 6 and 15 of 16 , respectively. The pattern of daily mortalities in Groups A, B and C was different (upper part of Fig. 5). In Group A there was mortality on Day 4 postinjection but not thereafter. In Group B mortality
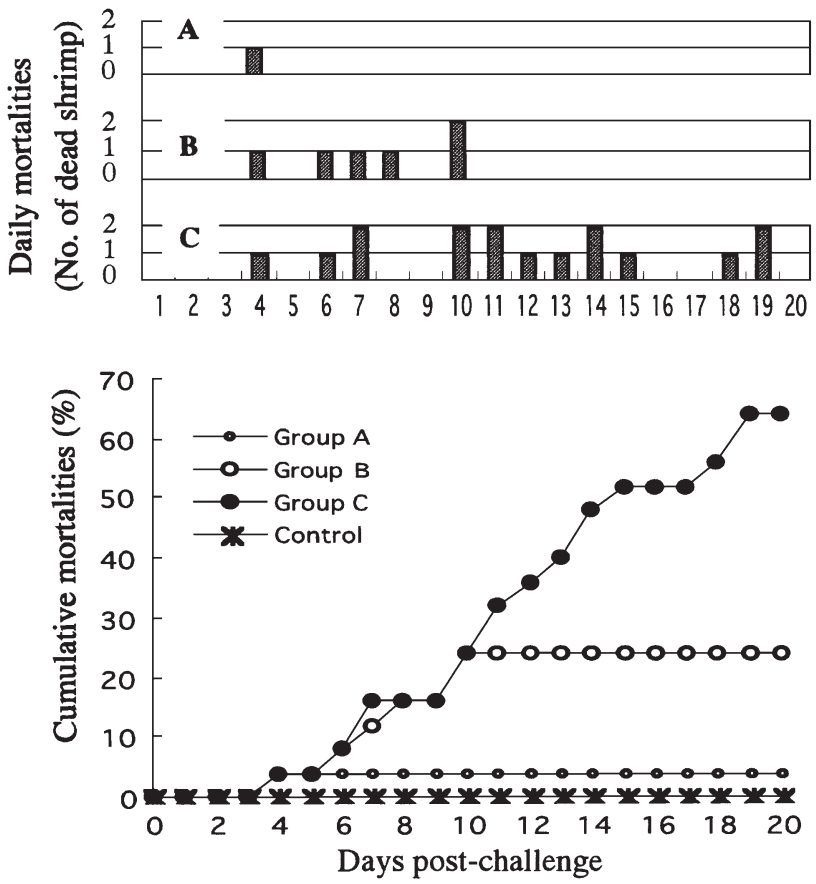

Fig. 5. Daily and cumulative mortalities of Penaeus japonicus challenged by IM injection with PRDV $\left(10^{-5}\right.$ dilution) and reared collectively in tanks with different management of dead shrimp (Expt 3). (A) Dead shrimp were immediately removed from the tank; (B) dead shrimp were separated by a net partition and removed from the tank twice a day; (C) dead shrimp were removed from the tank twice a day. Control shrimp were injected with PBS 
also began on Day 4 but ended on Day 10, while in Group C it ranged from Day 4 to Day 19. In other words, the period over which mortalities took place was progressively longer for each group. The rate of cannibalism in Group C was $87 \%$ (14 of 16 dead shrimp), but in the other groups there was no evidence of cannibalism.

\section{DISCUSSION}

In Expt 1 (Fig. 2), a significant difference in cumulative mortality of Penaeus japonicus was observed between individually reared shrimp $(1.2 \%)$ and collectively reared shrimp $(75.6 \%)$, although all originated from the same batch and received the same dose of the same virus preparation. This significant difference is thought to have resulted from rearing stress and horizontal transmission, i.e., there must have been higher stress and a higher opportunity for horizontal transmission of the virus in the Coll group.

In Expt 2b (Fig. 4), it was clearly seen that cumulative mortality was lower for shrimp reared at lower densities, at least in experimental PAV in Penaeus japonicus. The difference was significant between the high density and low density Coll groups, but not among the low density Coll group, middle density Coll group and Ind group. However, when the inoculation dose was higher, this density effect was not clearly shown (Fig. 3) because most of the challenged shrimp died rapidly due to the large inoculum of virus.

In Expt 3 (Fig. 5), effects of horizontal transmission of PAV by cannibalism or the waterborne route were examined. The significant difference in mortality observed between Groups C (64\%, where both cannibalism and waterborne transmission could occur) and B ( $24 \%$, where only waterborne transmission could occur) strongly supports the contention that high cumulative mortalities were associated with cannibalism. The effect of waterborne transmission on cumulative mortality was not important because there was no significant difference in mortality between Groups A $(4 \%$, with no cannibalism and reduced waterborne transmission) and B. In addition to the difference in cumulative mortality, there was a distinctly different pattern of mortality duration for Groups A, B and C. This suggests that the duration of mortality after that resulting from the initial injection was extended by additional viral dosing via cannibalism and the waterborne route. Obviously, surviving the initial injection did not protect the shrimp from additional challenges that took place within $15 \mathrm{~d}$ from the initial injection. This is not contradictory to our previous finding (Venegas et al. 2000), where a quasi-immune response against PAV was seen approximately $30 \mathrm{~d}$ after surviving an injection dose of the virus. Another experiment is required to know the exact time that the quasi-immune response begins in shrimp.

It has already been described that WSS can be horizontally transmitted via both waterborne contact and oral ingestion (Chou et al. 1998). Compound eyes, tails, pereiopods and pleopods of dead shrimp in the experimental PAV were often eaten by live shrimp. All of these organs can be infected abundantly with WSSV (Chang et al. 1996, Lo et al. 1997), and PAV has been successfully transmitted by feeding infected tissues not only in Penaeus japonicus but also in other shrimp and crab (Momoyama et al. 1999).

However, the role of cannibalism resulting in secondary infection and consequent high mortalities in experimental PAV often goes unrecognized since experimental shrimp are usually injected (or challenged by other methods) with high doses of the virus, as shown in Expt 2a. We proposed that a few shrimp in weak condition would die when they are injected with a small amount of PRDV. Even though very low mortality may occur from the first injection, the survivors would cannibalize the few dead or moribund shrimp and become infected secondarily by an additionally large amount of virus. Virus shed into the water from the dead or moribund shrimp may also be taken up via the waterborne route. This process would lead to rapid spread of disease especially in tanks with high shrimp densities. By contrast, shrimp kept at low densities would not experience this chain reaction and most shrimp would survive.

In Japan, 70 to 80 shrimp $\mathrm{m}^{-2}$ is recommended as the density for intensive culture of kuruma shrimp in tanks or ponds. However, higher densities may occur due to uneven distribution of shrimp, and this can increase cannibalism, especially in juveniles at night. Transmission of disease in animals with a cannibalistic nature, like shrimp, must increase the risk of exposure to an infective dose of a pathogen compared with animals with a less cannibalistic nature. Curiously, however, cannibalism was not observed in challenge trials of Penaeus japonicus (MBW $1.1 \mathrm{~g}$ ) with Vibrio penaeicida, the bacterium causing vibriosis in $P$. japonicus in Japan (Ishimaru et al. 1995), although it was reported to occur in luminous vibriosis of rock lobster Jasus verreauxi phyllosoma larvae infected by $V$. harveyi (Diggles et al. 2000). These observations indicate that the pattern of cannibalism and its role in disease transmission may depend on both host species and pathogen.

It is now generally accepted that stress is an important factor in outbreaks of infectious diseases in fish (Plumb 1992). It has also been proved that shrimp become more susceptible to pathogens when they are crowded and environmental conditions are stressful (Lightner \& Redman 1998). However, the 
substantial effect of stress on PAV mortality through reduced resistance of shrimp remains a subject for future studies.

Acknowledgements. This work was partly supported by the Japan Fisheries Resource Conservation Association. We are indebted to Dr M. Arimoto (Director) and other staff of the Kamiura Station of JASFA for their kind help in experiments. We are also grateful to Dr K. Momoyama of Yamaguchi Prefecture Fisheries Research Center, who kindly provided the virus source prepared from naturally PRDV-infected shrimp.

\section{LITERATURE CITED}

Chang PS, Lo CF, Wang YC, Kou GH (1996) Identification of white spot syndrome associated baculovirus (WSBV) target organs in the shrimp Penaeus monodon by in situ hybridization. Dis Aquat Org 27:131-139

Chang PS, Tasi DH, Wang YC (1998) Development and evaluation of a dot blot analysis for the detection of white spot syndrome baculovirus (WSBV) in Penaeus monodon. Fish Pathol 33:45-52

Chou HY, Huang CY, Wang CH, Chiang HC, Lo CF (1995) Pathogenicity of a baculovirus infection causing white spot syndrome in cultured penaeid shrimp in Taiwan. Dis Aquat Org 23:165-173

Chou HY, Huang CY, Lo CF, Kou GH (1998) Studies on transmission of white spot syndrome associated baculovirus (WSBV) in Penaeus monodon and P. japonicus via waterborne contact and oral ingestion. Aquaculture 164: 263-276

Diggles BK, Moss GA, Carson J, Anderson CD (2000) Luminous vibriosis in rock lobster Jasus verreauxi (Decapoda: Palinuridae) phyllosoma larvae associated with infection by Vibrio harveyi. Dis Aquat Org 43:127-137

Durand S, Lightner DV, Nunan LM, Redman RM, Mari J, Bonami JR (1996) Application of gene probes as diagnostic tools for white spot baculovirus (WSBV) for penaeid shrimp. Dis Aquat Org 27:59-66

Huang J, Song XL, Yu J, Yang CH (1995) Baculoviral hypodermal and hematopoietic necrosis: study on the pathogen and pathology of the explosive epidemic disease of shrimp. Mar Fish Res 16:1-10 (in Chinese with English abstract)

Inouye K, Miwa S, Oseko N and 3 others (1994) Mass mortalities of cultured kuruma shrimp Penaeus japonicus in Japan in 1993: electron microscope evidence of the causative virus. Fish Pathol 29:149-158 (in Japanese with English abstract)

Ishimaru K, Akagawa-Matsushita M, Muroga K (1995) Vibrio penaeicida sp. nov., a pathogen of kuruma prawns (Penaeus japonicus). Int J Syst Bacteriol 45:134-138

Kimura T, Yamano K, Nakano H, Momoyama K and 2 others (1996) Detection of penaeid rod-shaped DNA virus (PRDV) by PCR. Fish Pathol 31:93-98 (in Japanese with English abstract)

Lightner DV (1996) A handbook of pathology and diagnostic procedures for diseases of penaeid shrimp. World Aquaculture Society, Baton Rouge

Lightner DV, Redman RM (1998) Shrimp diseases and current diagnostic methods. Aquaculture 164:201-220

Lo CF, Leu JH, Ho CH, Chen CH and 8 others (1996) Detection of baculovirus associated with white spot syndrome (WSBV) in penaeid shrimp using polymerase chain reac- tion. Dis Aquat Org 25:133-141

Lo CF, Ho CH, Chen CH, Liu KF and 9 others (1997) Detection and tissue tropism of white spot syndrome baculovirus (WSBV) in captured brooders of Penaeus monodon with a special emphasis on reproductive organs. Dis Aquat Org 30:53-72

Magbanua FO, Natividad KT, Migo VP, Alfafara CG and 6 others (2000) White spot syndrome virus (WSSV) in cultured Penaeus monodon in the Philippines. Dis Aquat Org 42:77-82

Mohan CV, Shankar KM, Kulkarni S, Sudha PM (1998) Histopathology of cultured shrimp showing gross signs of yellow head syndrome and white spot syndrome during 1994 Indian epizootics. Dis Aquat Org 34:9-12

Momoyama K, Hiraoka M, Nakano H, Koube H and 2 others (1994) Mass mortalities of cultured kuruma shrimp, Penaeus japonicus, in Japan in 1993: histopathological study. Fish Pathol 29:141-148 (in Japanese with English abstract)

Momoyama K, Hiraoka M, Inouye K, Kimura T, Nakano H (1995) Diagnostic techniques of rod-shaped nuclear virus infection in the kuruma shrimp, Penaeus japonicus. Fish Pathol 30:263-269

Momoyama K, Hiraoka M, Venegas CA (1999) Pathogenicity of penaeid rod-shaped DNA virus (PRDV) to juveniles of six crustacean species. Fish Pathol 34:183-188

Mushiake K, Shimizu K, Satoh J, Mori K and 3 others (1999) Control of penaeid acute viremia (PAV) in Penaeus japonicus: selection of eggs based on the PCR detection of the causative virus (PRDV) from receptaculum seminis of spawned broodstock. Fish Pathol 34:203-207

Nakano H, Koube H, Umezawa S, Momoyama K and 3 others (1994) Mass mortalities of cultured kuruma shrimp Penaeus japonicus in Japan in 1993: epizootiological survey and infection trials. Fish Pathol 29:135-139 (in Japanese with English abstract)

Nonaka L, Venegas CA, Nishizawa T, Muroga K (1998) A method for nucleic acid extraction from Kuruma prawn for PCR detection of PRDV (penaeid rod-shaped DNA virus). Fish Pathol 33:115-121 (in Japanese with English abstract)

Nunan LM, Poulos BT, Lightner DV (1998) The detection of white spot syndrome virus (WSSV) and yellow head virus (YHV) in imported commodity shrimp. Aquaculture 160: $19-30$

Park JH, Lee YS, Lee S, Lee Y (1998) An infectious viral disease of penaeid shrimp newly found in Korea. Dis Aquat Org 34:71-75

Plumb JA (1992) Disease control in aquaculture. In: Shariff M, Subasinghe RP, Arthur JR (eds) Diseases in Asian aquaculture 1. Fish Health Section, Asian Fisheries Society, Manila, p 3-17

van Hulten MCW, Tsai MF, Schipper CA, Lo CF and 2 others (2000) Analysis of a genomic segment of white spot syndrome virus of shrimp containing ribonucleotide reductase genes and repeat regions. J Gen Virol 81:307-316

Venegas CA, Nonaka L, Mushiake K, Nishizawa T, Muroga K (2000) Quasi-immune response of Penaeus japonicus to penaeid rod-shaped DNA virus (PRDV). Dis Aquat Org 42:83-89

Wang YG, Hassan MD, Shariff M, Zamri SM, Chen X (1999) Histopathology and cytopathology of white spot syndrome virus (WSSV) in cultured Penaeus monodon from peninsular Malaysia with emphasis on pathogenesis and the mechanism of white spot formation. Dis Aquat Org 39: $1-11$

Wang YG, Lee KL, Najiah N, Shariff M, Hassan MD (2000) A 
new bacterial white spot syndrome (BWSS) in cultured tiger shrimp Penaeus monodon and its comparison with white spot syndrome (WSS) caused by virus. Dis Aquat Org 41:9-18

Wongteerasupaya C, Vickers JE, Sriurairatana S, Nash GL and 6 others (1995) A non-occluded, systemic baculovirus that occurs in cells of ectodermal and mesodermal origin and causes high mortality in the black tiger prawn Penaeus monodon. Dis Aquat Org 21:69-77

Editorial responsibility: Timothy Flegel,

Bangkok, Thailand
Wongteerasupaya C, Wongwisansri S, Boonsaeng V, Panyim $\mathrm{S}$ and 4 others (1996) DNA fragment of Penaeus monodon baculovirus PmNOB II gives positive in situ hybridization with white-spot viral infections in six penaeid shrimp species. Aquaculture 143:23-32

Zhan WZ, Wang YH, Fryer JL, Okubo K and 3 others (1999) Production of monoclonal antibodies (Mabs) against white spot syndrome virus (WSSV). J Aquat Anim Health $11: 17-22$

Submitted: March 8, 2001; Accepted: May 28, 2001

Proofs received from author(s): October 31, 2001 